Arq. Bras. Med. Vet. Zootec., v.68, n.6, p.1602-1608, 2016

\title{
Visceral Marek's disease in white-peafowl (Pavo cristatus)
}

\author{
[Doença de Marek visceral em pavão-branco (Pavo cristatus)] \\ G.R. Blume ${ }^{1}$, S.P. Cardoso ${ }^{1}$, M.L.B. Oliveira ${ }^{2}$, M.P. Matiolli², S.Y.M. Gómez ${ }^{3}$, J.L. Reis Júnior ${ }^{1}$, \\ F.J.F. Sant'Ana ${ }^{1 *}$, N.R.S. Martins ${ }^{3}$ \\ ${ }^{1}$ Laboratório de Diagnóstico Patológico Veterinário - UnB - Brasília, DF \\ ${ }^{2}$ Fundação Jardim Zoológico de Brasília - Brasília - DF \\ ${ }^{3}$ Setor de Doença das Aves - Escola de Veterinária - UFMG - Belo Horizonte, MG
}

\begin{abstract}
Marek's disease (MD) is a lymphoproliferative disorder caused by Gallid herpesvirus 2 (MDV) that infects mainly domestic gallinaceous birds although wild birds may occasionally be affected. The current report describes the anatomopathological and molecular findings of a case of MD in a white-peafowl (Pavo cristatus). The signs included apathy, hyporexia, and diarrhea. Grossly, 0.5 to $1.5 \mathrm{~cm}$ in diameter, yellow, soft nodules were observed in the skeletal muscle, lung, kidney, air sacs, small intestine, heart, ovary, ventriculus, and proventriculus. Microscopically, numerous atypical round neoplastic cells were noted. The molecular detection of MDV DNA was implemented to amplify part of the meq gene and products were sequenced for the phylogenetic analysis. Template DNA was obtained from tissues of the affected bird and from blood of all the gallinaceous birds of the Zoo. The expected amplicon for the partial amplification of MDV meq gene was obtained and the amplicons were sequenced. Sequences obtained enabled grouping the strain (accession no. KT768121) with MDV serotype 1 strains from the GenBank. Based on the anatomopathological and molecular findings, the diagnosis of MD in a whitepeafowl was reached, and to the authors' knowledge, no previous report regarding MD was published in Pavo cristatus.
\end{abstract}

Keywords: Marek's disease, lymphoma, oncogenic virus, MDV, herpesvirus

\section{RESUMO}

Doença de Marek (MD) é uma desordem linfoproliferativa causada pelo Gallid herpesvirus 2 (MDV), que infecta principalmente galináceos domésticos, porém aves silvestres podem ser ocasionalmente afetadas. O presente relato descreve os achados anatomopatológicos e moleculares de um caso de MD em um pavão-branco (Pavo cristatus). Os sinais clínicos incluíram apatia, hiporexia e diarreia. Macroscopicamente, foram observados nódulos macios, de 0,5 a 1,5cm de diâmetro, no músculo esquelético, no pulmão, nos rins, nos sacos aéreos, no intestino delgado, no coração, no ovário, no ventrículo e no proventrículo. Microscopicamente, numerosas células redondas neoplásicas atípicas foram notadas. A deteç̧ão molecular do DNA do MDV foi implementada para amplificar parte do gene meq, e os produtos foram sequenciados para análise filogenética. DNA foi obtido de tecidos de aves afetadas e do sangue de todos os galináceos do zoológico. A esperada amplificação de parte do gene meq de MDV amplificado foi ampliada e sequenciada. As sequências obtidas permitiram o agrupamento da cepa (acesso KT768121) com cepas do sorotipo 1 de MDV do GenBank.. O diagnóstico de MD em pavão-branco foi obtido com base nos achados anatomopatológicos e moleculares e, pelo conhecimento dos autores, não há relatos anteriores publicados de MD em Pavo cristatus.

Palavras-chave: doença de Marek, linfoma, vírus oncogênico, MDV, herpesvírus

Recebido em 12 de novembro de 2015

Aceito em 29 de março de 2016

*Autor para correspondência (corresponding author)

E-mail: santanafjf@yahoo.com 


\section{INTRODUCTION}

Marek's disease (MD) is a lymphoproliferative disorder caused by Marek's disease virus (MDV) serotype 1 of the Family Herpesviridae, subfamily Alphaherpesvirinae, genus Mardivirus and species Gallid herpesvirus 2 (Murata et al., 2012). MDV replicates in the feather follicle epithelium and natural desquamation (dander) is readily disseminated in premises and inhaled by susceptible birds of genus Gallus (Schat and Nair, 2008). The disease occurs in the domestic chicken and related birds of order Galliformes (Schat and Nair, 2008). However, little is known regarding the disease in wild species of other genera (Cho and Kenzy, 1975).

The transmission to migratory birds which share the environment with chickens is considered (Schat and Nair, 2008). In wild species, MD is more prevalent in captive birds, as compared to free living, although the actual prevalence is unknown (Murata et al., 2012). In peafowl, previous reports describe a lymphoproliferative disease, one case of reticuloendotheliosis (Miller et al., 1998) and two others without the determination of the etiology (Kaliner and Miringa, 1972; Sah et al., 1973). In San Diego Zoological Garden (California, USA), the virological and serological evaluation of 111 birds, of 49 species and 14 orders, resulted in the detection of MDV in ten birds, all of genus Gallus (Cho and Kenzy, 1975).

Clinical signs may vary with the MDV strain and the degree of effect in organs, but may be mostly unspecific, including apathy, weight loss, diarrhea, and dyspnea, although the type of paralysis of limbs would be indicative. Most birds would not develop clinical signs and function as lifelong reservoirs and virus source, expressing MDV in cycles (Payne and Venugopal, 2000). At necropsy, whitish soft metastases may be disseminated in viscera, mainly liver, spleen, thymus, heart, kidneys, gonads, lungs, proventriculus, mesentery, intestines, cloacal bursa, adrenal, pancreas, skeletal muscle, iris, and skin (Schat and Nair, 2008). Microscopically, tumors consist of pleomorphic $\mathrm{T}$ lymphocytes (Payne and Venugopal, 2000). Virus isolation, immunohistochemistry or DNA detection by PCR are required for the definitive diagnosis and to differentiate from other lymphoproliferative diseases such as avian leukosis, reticuloendotheliosis, and lymphoproliferative disease of turkeys (Payne and Venugopal, 2000; Schat and Nair, 2008). The aim of this article is to describe the clinical, pathological, and molecular findings of a natural MDV occurrence in white peafowl (Pavo cristatus).

\section{CASUISTIC}

An adult female peafowl of the Jardim Zoológico de Brasília (FJZB) (DF, Brazil) died after a month-long clinical disease which included apathy, hyporexia, and diarrhea, despite being medicated with enrofloxacin (Baytril ${ }$, Bayer S.A., São Paulo, Brazil), sulfamethoxazol plus trimethoprim (Trisulfin $\AA$, Ouro Fino, Cravinhos, Brazil), and metronidazole (Flagyl ${ }^{\circledR}$, SanofiAventis Farmacêutica Ltda, Suzano, Brazil). The bird was found dead in the premises and after a preliminary examination, all the gallinaceous (Galliformes; $n=36$ ) (Tab. 1) birds of the premises were examined, taking a blood sample for PCR. Blood samples $(1 \mathrm{~mL})$ were collected at the ulnar or at the brachial vein in anticoagulant (EDTA).

Table 1. Species of order Galliformes evaluated by PCR for Marek's disease virus

\begin{tabular}{lc}
\hline \multicolumn{1}{c}{ Species } & $\begin{array}{c}\text { Number } \\
\text { sampled }\end{array}$ \\
\hline Red-throated piping guan (Aburria cujubi) & 1 \\
Black-fronted piping guan (Aburria & 4 \\
jacutinga) & \\
Black curassow (Crax alector) & 1 \\
Red-billed curassow (Crax blumembachii) & 1 \\
Bare-faced curassow (Crax fasciolata) & 3 \\
Razor-billed curassow (Pauxi tuberosum) & 5 \\
Nocturnal curassow (Nothocrax urumutum) & 2 \\
Indian peafowl (Pavo cristatus) & 8 \\
Dusky-legged guan (Penelope obscura) & 1 \\
Rusty-margined guan (Penelope & 4 \\
superciliaris) & \\
Chestnut-bellied guan (Penelope & 5 \\
ochrogaster) & \\
Silver pheasant (Lophura nycthemera) & 2
\end{tabular}

The hemogram revealed non-regenerative anemia and leukopenia, with approximately $98 \%$ of lymphocytes reactive, piknotic and with a few in mitosis. At necropsy, poorly delimited, soft, 0.5 to $1.5 \mathrm{~cm}$ in diameter yellow nodules were noted in the pectoral muscle (Fig. 1A), lungs, kidneys, air sacs, small intestine, heart (Fig. 1B), ovary, gizzard (ventriculus), and proventriculus. 
All samples were fixed in buffered formaldehyde $10 \%$, processed routinely for histopathology, and stained with hematoxylin-eosin (HE). Tissue samples from kidneys and breast muscle were also collected and stored frozen for PCR. The histopathology revealed densely cellular neoplasia without capsule and infiltrating into the affected organs. The neoplasma was composed of atypical lymphocytes arranged in layers maintained by a scarce fibrovascular stroma (Fig.
1C and 1D). Neoplastic cells presented scarce, with distinct limits, eosinophilic, and homogenous cytoplasm. The nuclei were central, rounded, single, basophilic with loose chromatin and with one to four separate nucleoli. Discrete anisocytosis and moderate anisokaryosis with a 4:1 nucleus-cytoplasm ratio were evident. Within ten high magnification (1000x) fields, 27 mitoses were observed.

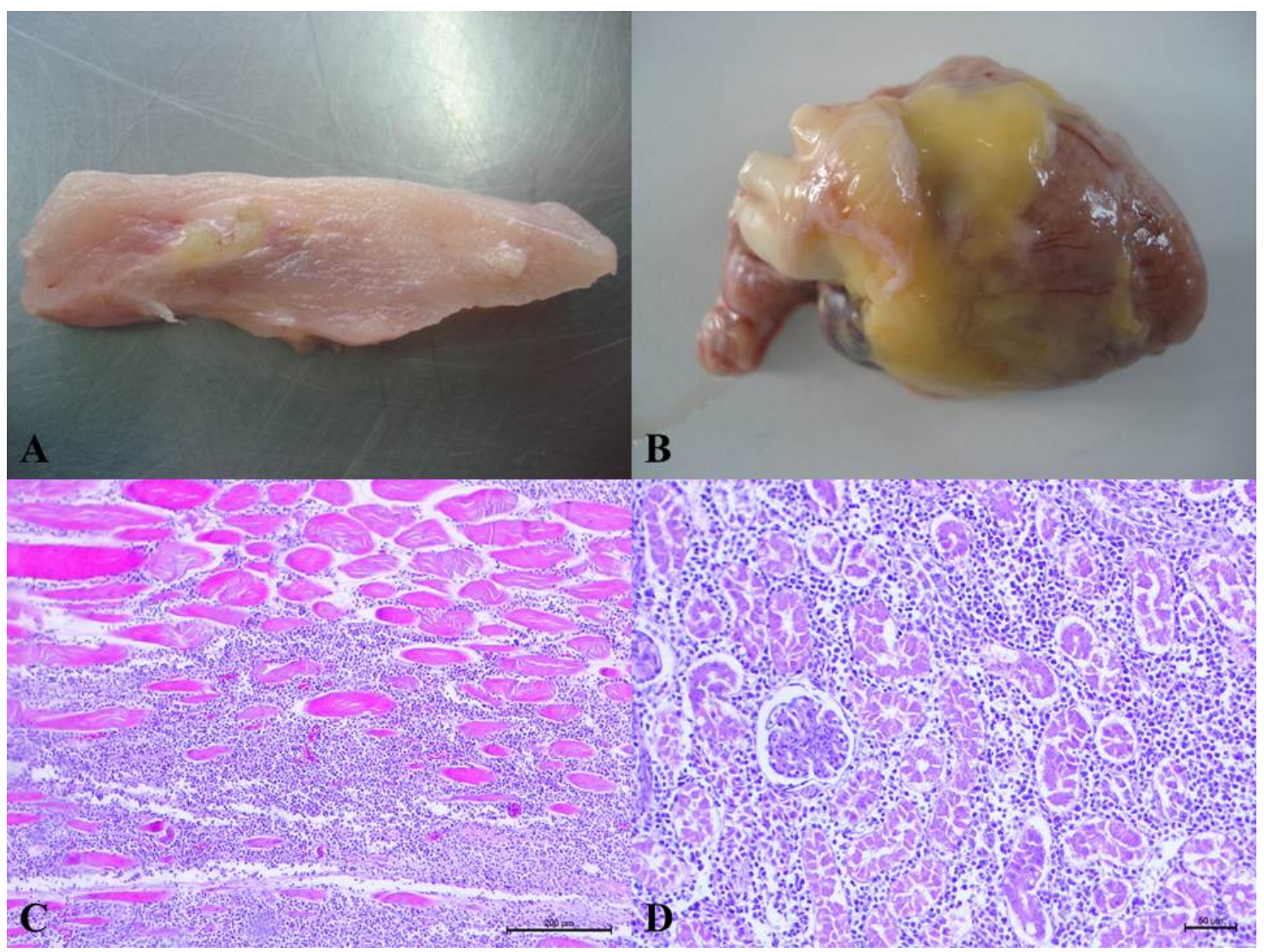

Figure. 1. Visceral Marek's disease in a female white-peafowl (Pavo cristatus). A. Gross aspect of skeletal muscle showing $0.5-1.5 \mathrm{~cm}$ yellow nodules (arrows). B. Heart presents numerous multifocal to coalescent yellow nodules affecting pericardium and myocardium (arrows). C. Pectoral muscle. Proliferation of neoplastic lymphocytes is observed among the skeletal fibers. Note some atrophied fibers inside the neoplasm. HE. D. Kidney. Neoplastic cells infiltrate and expand the interstitium. HE.

DNA extractions were performed by silica adsorption. Three volumes of $\mathrm{NaI}(6 \mathrm{M})$ were added to one volume of tissue or blood (approximately $200 \mu \mathrm{l}$ of tissue or blood and $600 \mu \mathrm{l}$ of $\mathrm{NaI}$ ), macerated and incubated at $55^{\circ} \mathrm{C} / 15 \mathrm{~min}$. in an end-over-end mixer. The mixture was centrifuged $(2,000 \mathrm{xg} / 30 \mathrm{~s})$ and the supernatant recovered with pipette, and $50 \mu 1$ of silicon dioxide suspension (Sigma Chemical Co.,
St. Louis, USA) added, homogenized with vortex and incubated in an end-over-end mixer (SpeciMix, Thermolyne) for $10 \mathrm{~min}$ at room temperature $\left(22^{\circ} \mathrm{C}\right)$. The mixture was centrifuged $(2,000 \mathrm{xg} / 30 \mathrm{~s})$, the supernatant discarded and the pellet washed in NaI, centrifuged $(2,000 \mathrm{xg} / 30 \mathrm{~s})$ and the pellet washed twice in washing buffer (ethanol $50 \% 50 \mathrm{mM}$ Tris- $\mathrm{HCl} \mathrm{pH} 8.0,10 \mathrm{mM}$ EDTA $\mathrm{pH} 8.0)$ by centrifugation $(2,000 \mathrm{xg} / 30 \mathrm{~s})$, 
with the supernatant discarded. One $\mathrm{ml}$ of acetone was added to the pellet, vortexed, centrifuged $(2,000 \mathrm{xg} / 30 \mathrm{~s})$, the supernatant discarded and any residue evaporated $\left(56^{\circ} \mathrm{C} / 10 \mathrm{~min}\right)$. The adsorbed DNA to silicon microbeads was eluted with $50 \mu \mathrm{l}$ TE $(5 \mathrm{mM}$ Tris$\mathrm{HCl} \mathrm{pH}$ 8.0, 0.5mM EDTA pH 8.0), incubated at $50^{\circ} \mathrm{C} / 5 \mathrm{~min}$ in the end-over-end mixer and centrifuged $(2,000 \mathrm{xg} / 30 \mathrm{~s})$. The supernatant was removed with pipette and stored $\left(-20^{\circ} \mathrm{C}\right)$ until used as template for PCR. The meq-specific oligonucleotide primers used 5'ATGTCTCAGGAGCCAGAGCCGGCGCT-3', and 5'-GGGGCATAGACGATGTGCTGCTGAG-3' amplify a sequence of the meq gene with a $1,062 \mathrm{bp}$ product. PCR was performed in $50 \mu \mathrm{l}$ volumes containing $1.5 \mathrm{mM} \mathrm{MgCl} 2,0.1 \mu \mathrm{M}$ of each primer, 500ng of template DNA, $0.2 \mathrm{mM}$ of dNTP mix and 0.2 unit of the Taq DNA polymerase (Phoneutria, Belo Horizonte, Brazil). After initial $94^{\circ} \mathrm{C} / 5 \mathrm{~min}$ incubation, the 40 -cycle PCR incubation protocol was run at $94^{\circ} \mathrm{C} / 60 \mathrm{~s}$, $57^{\circ} \mathrm{C} / 60 \mathrm{~s}$ and $72^{\circ} \mathrm{C} / 90 \mathrm{~s}$, with a final incubation at $72^{\circ} \mathrm{C} / 7 \mathrm{~min}$.

The proviral DNA of avian leukosis virus was investigated using previously described primers for fowl glioma-inducing virus (FGV) (Hatai et al., 2005). A nested PCR for FGV with external primers EnvFwd3 (59-ACGTTGCCGGAATGTGTTGT-39) and L7Krev (59-CTATACACACCCTAGTCCC-39) and internal primers 5FGOG (59TGTAGGCGGGCTCTTGTATT-39) and 3FGOG (59-TTGTCGGTCAAGCCTTGCCTT39), was used to amplify a FGV non-coding region with a $135 \mathrm{bp}$ product.

PCR products were purified for sequencing with polyethylene glycol (PEG). Single band PCR products, as determined by electrophoresis, were purified. Equal volumes of PEG $800020 \%$ and amplicon were stirred for $15 \mathrm{~s}$ and incubated for $15 \mathrm{~min}$ at $37 \mathrm{C}$. The mix was centrifuged at $12,000 \mathrm{xg}$ for $15 \mathrm{~min}$ and the supernatant carefully removed with pipette and discarded. The sediment was washed twice with $100 \mu$ of $80 \%$ ethanol added slowly without disturbing the pellet and centrifuged for $5 \mathrm{~min}$ at $12,000 \mathrm{xg}$. The supernatant was discarded by inversion, the tube was incubated at $37^{\circ} \mathrm{C}$ for ethanol evaporation and $10-15 \mu 1$ of ultrapure water were added. The sediment was suspended by pipetting and the purified DNA fragment size was confirmed by electrophoresis on $1.5 \%$ agarose gel in $0.53 \mathrm{TBE}$ and quantified (NanoVue, GE Healthcare, Little Chalfont, United Kingdom).

The purified product was sequenced by the dideoxynucleotide method using a sequencing kit (BigDyeH Terminator Mix, Applied Biosystems, Carlsbad, USA) according to the manufacturer instructions. One microliter of each purified product was used. The reaction was performed using $1 \mu 1$ of each primer (forward and reverse) at 10pmol, $1 \mu \mathrm{l}$ of BigDye, $1 \mu \mathrm{l}$ of SaveMoney ${ }^{\mathrm{TM}}$ buffer (Applied Biosystems) and ultrapure water $18.2 \mathrm{M} \Omega$ q.s.p. to $10 \mu \mathrm{l}$. Reactions were performed in a thermocycler (PTC-100, MJ Research, Inc.) with denaturation at $96 \mathrm{C}$ for 15 $\mathrm{sec}$, annealing of primer at $50^{\circ} \mathrm{C}$ for $15 \mathrm{sec}$, and extension at $60^{\circ} \mathrm{C}$ for $4 \mathrm{~min}$, repeated 30 times. The sequencing PCR product was purified by isopropanol and ethanol precipitation and homogenized in $\mathrm{Hi}-\mathrm{Di}^{\mathrm{TM}}$ formamide (Invitrogen, São Paulo, Brazil) and rapidly denatured at $95^{\circ} \mathrm{C}$ / 2 min and immediately placed on ice. The analyses were made in an automated capillary electrophoresis system (ABI Prism 310 Genetic Analyzer, Perkin Elmer, Waltham, USA) in the Laboratory of Genetics, Department of Animal Sciences (Escola de Veterinária UFMG, Belo Horizonte, Brazil). The generated sequences compositions were compared with sequences available in the database of the National Center for Biotechnology Information (NCBI, 2015). The Basic Local Alignment Search Tool (BLAST 2.0), BLASTn, and BLASTx (BLAST, 2015) software, developed by the NCBI, were used to determine similarity of nucleotide and amino acid compositions, respectively. The electropherograms of sequences of sense and antisense strands were analyzed using BioEdit. All final sequences generated were compared with sequences available in the database of the NCBI. The nucleotide and amino acid sequences were aligned with sequences obtained in the GenBank using Clustal $X$ software, in the Molecular Evolutionary Genetics Analysis MEGA version 5.0 for Windows. The confidence on the topology of the phylogenetic tree was insured by 1,000 bootstrap oversampling. The nucleotide and the amino acid substitutions were assessed using the Kimura 2 parameter or the JTT for amino acid substitution, respectively. The expected molecular mass product $(1,062 \mathrm{bp})$ was obtained as revealed by electrophoresis. No amplicon was obtained for avian leukosis virus. 
Comparing the sequenced PCR products obtained from tumors with sequences on GenBank revealed identity with Gallid herpesvirus 2 (MDV) (Fig. 2). However, MDV DNA was not detected in any of the other birds $(n=36)$ examined. The phylogenetic analysis of the MDV is based on the the meq gene partial DNA sequence, performed by the neighborjoining method using MEGA version 5.0 software packages and bootstrap confidence limits for 1000 replicates. The isolate Gallid herpesvirus 2 Marek's disease virus type 1 Brasilia 1 was identified using the nomenclature of strain or isolate name referring to the geographic location. The partial sequence of meq gene was deposited in the GenBank with the Accession number KT768121.

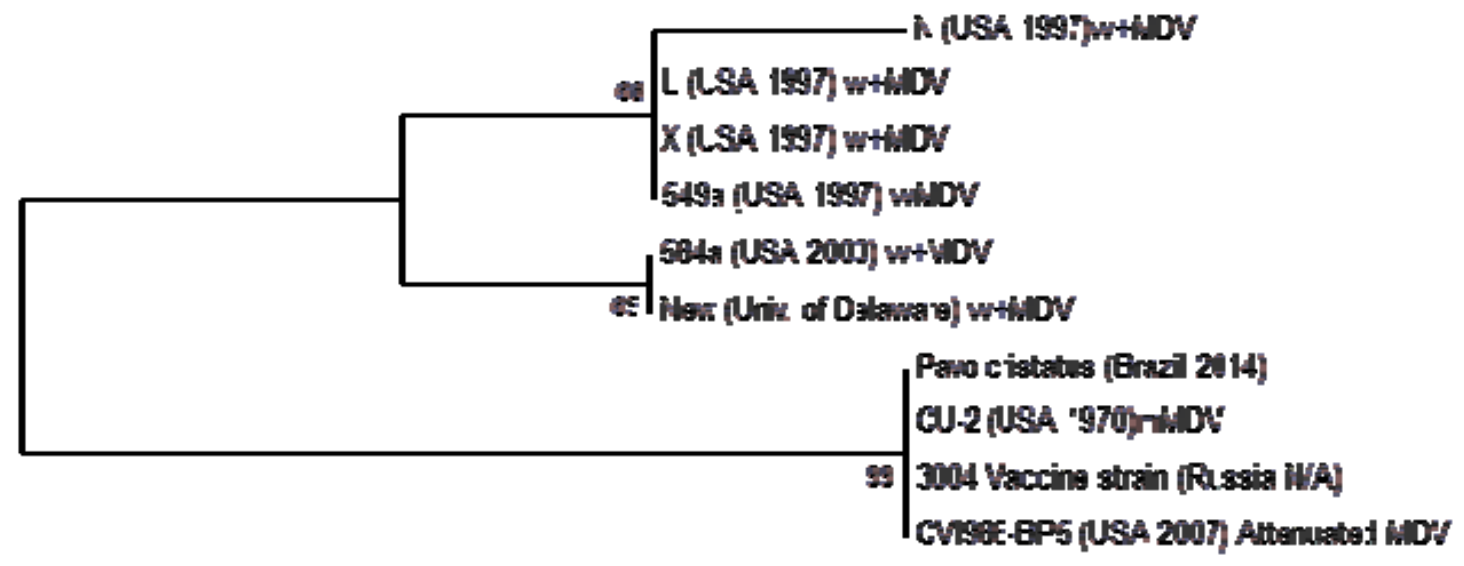

\section{Dont}

Figure 2. Evolutionary relationships of isolate Gallid herpesvirus 2 (Marek's disease virus) type 1 Brasilia 1 (Accession number KT768121) from peafowl (Pavo cristatus). The evolutionary history was inferred using the Neighbor-Joining method (Saitou \& Nei, 1987). The optimal tree with the sum of branch length $=0.01401755$ is shown. The percentage of replicate trees in which the associated taxa clustered together in the bootstrap test (1000 replicates) is shown next to the branches. The tree is drawn to scale, with branch lengths in the same units as those of the evolutionary distances used to infer the phylogenetic tree. The evolutionary distances were computed using the Tamura-Nei method and are in the units of the number of base substitutions per site (Tamura \& Nei, 1993). The analysis involved 10 nucleotide sequences. Codon positions included were $1 \mathrm{st}+2 \mathrm{nd}+3 \mathrm{rd}+$ Noncoding. All positions containing gaps and missing data were eliminated. There were a total of 575 positions in the final dataset. Evolutionary analyses were conducted in MEGA5 (Tamura et al., 2011). Notes: vv+ very virulent plus MDV; vvMDV very virulent MDV; mMDV mildly virulent MDV.

\section{DISCUSSION}

The anatomopathological evaluation and mainly the molecular detection were conclusive for the diagnosis of MD in peafowl. No previous report of MD was found for the white peafowl. Some reports, however, describe lymphomatosis in peafowl (Kenzy et al., 1964; Kaliner and Miringa, 1972; Sah et al., 1973; Miller et al., 1998). MD is usually diagnosed in domestic gallinaceous birds and descriptions in other species of birds are scarce.
The phylogenetic analysis of the MDV isolate, as based on the meq gene partial DNA sequence, enabled grouping the isolate with serotype 1 MDV vaccine strains, such as CVI988 (The Netherlands; attenuated MDV), CU-2 mMDV (USA; mild MDV) and strain 3004 (Russia; attenuated MDV). Such identity was surprising, considering the mild or attenuated character of related strains in group.

The clinical signs, gross and microscopic lesions were compatible with the literature (Schat and Nair, 2008). MDV is replicated initially in 
B-lymphocytes, then in the feather follicle epithelium and subsequently integrates genomically into T lymphocytes. Except for the lymphoproliferative disease, the atrophy of lymphoid organs and immunodepression (Payne and Venugopal, 2000), were not detected in the present study. Lymphoproliferative diseases must be differentiated microscopically at histopathology and the etiology may be determined through the genomic detection and characterization. Lymphoid leukosis presents homogenous lymphoblast proliferations which are distinguishable from the MD that usually has discrete anisocytosis and moderate anisokaryosis as found in the current study (Payne and Venugopal, 2000). MD is an infectious disease of worldwide occurrence, mostly in immature chickens (Schat and Nair, 2008). In the present report, the white peafowl was an adult bird. The reasons for differences between chicken and peafowl regarding the susceptibility to infection and to the behavior to the MD lymphoproliferative disease are not known.

All other gallinaceous birds captive at the FJZB were evaluated for MD and ALV genome and resulted negative. The source of MDV remains to be determined. Occasional local migratory birds visit the FJZB and the possibility of such birds previously visiting free-range chickens. However, the local geographical range migratory birds, such as the cattle egret (Bubulcus ibis) and the white-faced whistling duck (Dendrocygna viduata) are not considered a source of MDV. Free-range chickens may act as natural reservoir of MDV and a few individuals from flocks regularly succumb to MD in the rural areas of Minas Gerais, Brazil, (unpublished findings) and possibly other Brazilian states.

MD has been one of the most important viral diseases of the poultry industry since the prosperity of the industry has been enabled through its control by vaccination (Payne and Venugopal, 2000). However, although chickens are by far the most important host for MDV, quail, turkey, and pheasant are also susceptible species to infection and disease. In addition to chicken, gamefowl (Kenzy et al., 1964), native gallinaceous breeds (Grewal et al., 1977), and jungle fowl (Cho and Kenzy, 1975) are susceptible to MDV infection and tumor formation. Most other domestic avian species including duck, partridge, peafowl, pigeon, and sparrow (Baxendale, 1969; Kenzy and Cho, 1969) are considered refractory to MDV infection.

A novel GaHV-3 has been described in the mountain peacock pheasant (Polyplectron inopinatum), the Malayan peacock pheasant (Polyplectron malacense), and the Congo peafowl (Afropavo congensis), with hepatocyte necrosis and nuclear eosinophilic inclusions, which showed 92\% identity to GaHV-3, Marek's disease virus serotype 2 , despite serotype 2 strains are considered not pathogenic in chickens. However, no description of MDV tumors was found in the literature for peacock (Seimon et al., 2012).

Based on the clinical, anatomopathological, and molecular results, the diagnosis of MD was confirmed in a peafowl of the zoological garden of Brasília, Midwestern Brazil. The evaluation of all other gallinaceous birds resulted negative for MDV and the source of infection, with the possibility of a role for free-range chickens, which remains to be determined.

\section{ACKNOWLEDGEMENTS}

Authors are indebted to CAPES, CNPq, and FAPEMIG for financial support and FJZB for the availability of birds.

\section{REFERENCES}

BAXENDALE, W. Preliminary observations on Marek's disease in ducks and other avian species. Vet. Rec., v.85, p.341-342, 1969.

BLAST, National Center for Biotechnology Information, http://www.ncbi.nlm.nih.gov. Accessed on 09/14, 2015.

CHO, B.R.; KENZY, S.G. Virologic and serologic studies of zoo birds for Marek's disease virus infection. Infect. Immun., v.11, p.809-814, 1975.

GREWAL, G.S.; SINGH, B.; SINGH, H.P. Epidemiology of Marek's disease: incidence of viral specific antigen in feather follicle epithelium of domestic fowl of Punjab, India. Indian J. Poult. Sci., v.12, p.1-5, 1977. 
HATAI, H.; OCHIAI, K.; TOMIOKA, Y. et al. Nested polymerase chain reaction for detection of the avian leukosis virus causing so-called fowl glioma. Avian Pathol., v.34, p.473-479, 2005.

KALINER, G.; MIRINGA, E.N. Malignant lymphoid neoplasia in a peahen (Pavo cristatus). Avian Dis., v.16, p.1115-1117, 1972.

KENZY, S.G.; CHO, B.R. Transmission of classical Marek's disease by affected and carrier birds. Avian Dis., v.13, p.211-214, 1969.

KENZY, S.G.; MCLEAN, G.S.; MATHEY, W.J.; LEE, H.C. Preliminary observations of gamefowl neurolymphomatosis. J. Nat. Cancer Inst., v.17, p.121-130, 1964.

MILLER, P.E.; PAUL-MURPHY, J.; SULLIVAN, R. et al. Orbital lymphosarcoma associated with reticuloendotheliosis virus in a peafowl. J. Am. Vet. Med. Assoc., v.213, p.377380,1998 .

MURATA, S.; HAYASHI, Y.; KATO, A. et al. Surveillance of Marek's disease virus in migratory and sedentary birds in Hokkaido, Japan. Vet. J., v.192, p.538-540, 2012.

NCBI, National Center for Biotechnology Information, http://www.ncbi.nlm.nih.gov. Accessed on 09/14, 2015.

PAYNE, L.N.; VENUGOPAL, K. Neoplastic diseases: Marek's disease, avian leukosis and reticuloendotheliosis. Rev. Sci. Tech. Off. Int. Epizoot., v.19, p.544-564, 2000.
SAH, R.L.; ACHARJYO, L.N.; MOHANTY, G.C. Lymphomatosis in a peahen and a pied mynah. Poult. Sci., v.52, p.1210-1212, 1973.

SAITOU, N.; NEI, M. The neighbor-joining method: a new method for reconstructing phylogenetic trees. Mol. Biol. Evol., v.4, p.406425, 1987.

SCHAT, K.A.; NAIR, V. Marek's disease. In: SAIF, Y.M.; BARNES, H.J.; GLISSON, J.R. et al. (Eds.). Diseases of poultry. 12.ed. Ames: State Press, 2008. p.458-520.

SEIMON, T.A.; MCALOOSE, D.; RAPHAEL, B. et al. A novel herpesvirus in three species of pheasants: mountain peacock pheasant (Polyplectron inopinatum), Malayan peacock pheasant (Polyplectron malacense), and Congo peafowl (Afropavo congensis). Vet. Pathol., v.49, p.482-491, 2012

TAMURA, K.; NEI, M. Estimation of the number of nucleotide substitutions in the control region of mitochondrial DNA in humans and chimpanzees. Mol. Biol. Evol., v.10, p.512-526, 1993.

TAMURA, K.; PETERSON, D.; PETERSON, $\mathrm{N}$. et al. MEGA5: molecular evolutionary genetics analysis using maximum likelihood, evolutionary distance, and maximum parsimony methods. Mol. Biol. Evol., v.28, p.2731-2739, 2011. 